\title{
Half-sib progenies evaluation in velvet grass
}

\author{
Andréa Mittelmann ${ }^{1}$, and Elizandra Döring Buchweitz ${ }^{2}$
}

Received 13 May 2009

Accepted 19 May 2010

\begin{abstract}
Velvet grass (Holcus lanatus L.) has a great potential use for winter pasture in subtropical regions due to its good establishment, persistence, high forage production, cold resistance, palatability and tillering ability. The objective of this work was to estimate genetic variability and heritability of agronomic traits and to identify superior progenies. Sixty half-sib progenies were assessed for natural height at the vegetative stage ( $\mathrm{NH}$ ), plant diameter (diameter), heading date (cycle), final height (after flowering) (FH), and tiller number (tillers). Difference among progenies was observed for all traits. Heritability estimates were $38 \%, 32 \%, 92 \%, 57 \%$ and $64 \%$ for NH, diameter, cycle, FH and tillers, respectively. The highest genetic gain estimate was $30.77 \%$ for the tiller number. There is genetic variability for all the traits and gains after selection among halfsib progenies can be expected.
\end{abstract}

Key words: Pasture, Holcus lanatus, additive variance, heritability, selection gain.

\section{INTRODUCTION}

Velvet grass (Holcus lanatus L.) is a grass from the temperate areas of Europe and Asia and from Canary Islands and currently it is widely distributed in temperate regions around the world (Watt 1978, Pitcher and Russo 2003).

It is a cold season, allogamic plant (Watt 1978), which in Brazil behaves as an annual or biannual (Araújo 1956, Oliveira et al. 2001, Pitcher and Russo 2003). It is a competitive species that tolerates a wide range of edaphoclimatic factors (Watt 1978). This species adapts mainly to humid lands (Klitsch 1965) and can survive during short periods of drought (Pitcher and Russo 2003), also being a species resistant to cold (Oliveira et al. 2001, Pitcher and Russo 2003).
Its adaptation to soil $\mathrm{pH}$ variation is wide, having as optimal pH conditions a range from 5.0 to 7.5 (Pitcher and Russo 2003). Velvet grass prefers soils with high organic matter content (Araújo 1956) and responds well to fertilization (Oliveira et al. 2001). The adaptation in poor soils and the high competitiveness of velvet grass are due to its radicular system, which is well developed and aggressive (Watt 1978).

It has been considered to be equivalent to Italian ryegrass at intermediary fertility conditions and moderate stocking rate (Rumball 1980). In Uruguay, it surmounts the Italian ryegrass in dry matter production in the critical periods of autumn, winter and the beginning of the spring season, with similar quality (Bemhaja 1993).

The species was introduced by the veterinarian Charles Vincent at Ponta Grossa, the State of Paraná, Brazil,

\footnotetext{
${ }^{1}$ Embrapa Gado de Leite/Clima Temperado, C.P. 403, 96001-970, Pelotas, RS, Brazil. *E-mail: andream@cnpgl.embrapa.br.

${ }^{2}$ Universidade Estadual Paulista Júlio de Mesquita Filho, Faculdade de Ciências Agrárias e Veterinárias de Jaboticabal, Departamento de Biologia Aplicada à Agropecuária, Via de acesso Prof. Paulo Donato Castellane, km 5, Campus Universitário, 14.884-900, Jaboticabal, SP, Brazil.
} 
in 1912. It adapted perfectly to the edaphoclimatic conditions of the State of Rio Grande do Sul, in which it was introduced in 1917 at the Posto Zootécnico de Viamão, where it started to disseminate to the rest of the State. Currently, it occurs spontaneously in pasture areas (Araújo 1956).

According to Oliveira et al. (2001), the species produces forage of intermediary quality; however, it has high palatability. Good acceptance of velvet grass forage by the cattle was described by Araújo (1956). In the experiments performed at the Embrapa Temperate Agriculture, velvet grass has shown a protein content equal to the tall fescue (Festuca arundinacea) and superior to Bromus catharticus (Gomes and Reis 2000).

Velvet grass has high tillering ability and produces forage earlier than other perennial temperate species (Araújo 1956, Oliveira et al. 2001). This grass evidenced a perfect adaptation to the environment and also a good productivity and may be used as pasture or hay (Araújo 1956). Other advantages of this species are the intense flowering and high seed production in the establishment year (Araújo 1956, Moraes et al. 2000). Besides the forage production, velvet grass might be used in soil erosion control and the recovery of soils with low fertility and acidity.

Due to all these traits, velvet grass is a very interesting winter pasture for regions with subtropical climate and, among the winter perennial grasses, the best adapted to Southern Brazil. However, there are no commercial varieties in the country and no seed is available for farmers.

The first step for the development of velvet grass varieties is to know the existing variability in the most important traits as well as the genetic parameters of its populations. Therefore, the objective of this work was to estimate genetic variability and assess the heritability for traits of agronomic interest in a velvet grass population collected in the State of Rio Grande do Sul, Brazil, through the evaluation of half-sib progenies, and to identify superior progenies for each trait.

\section{MATERIAL AND METHODS}

The experiment was accomplished at the Low Lands Experimental Station of Embrapa Temperate Agriculture in the municipality of Capão do Leão (lat $31^{\circ}$ 52’ 00" S, long $52^{\circ} 21^{\prime} 24^{\prime \prime}$ W, alt 13.24 m asl), State of Rio Grande do Sul, Brazil, during 2003. Sixty half-sib progenies collected from a population in the municipality of Bagé, State of Rio Grande do Sul, Brazil were studied. The Uruguayan commercial cultivar La Magnolia was used as a check.
Progenies were sown in trays on May $22^{\text {nd }}$, and trays were kept in the greenhouse. On July $10^{\text {th }}$, the seedlings were transplanted to the field. The experimental design was a randomized block, with three replications. Each plot was represented by one line with ten plants. Spacing among lines and among plants within lines was $0.3 \mathrm{~m}$.

On September $29^{\text {th }}$, in the vegetative stage of the plants, the first assessments were made, measuring the natural height $(\mathrm{NH}, \mathrm{cm})$ and plant diameter (diameter, $\mathrm{cm}$ ). Heading started at October $8^{\text {th }}$, and was evaluated weekly. Heading date (cycle) was measured as days from sowing to the emission of the first panicle. After flowering, two traits were assessed: final height $(\mathrm{FH}, \mathrm{cm})$, from the ground level until the insertion of the flag leaf, and tiller number (tillers): counting undertaken on November $27^{\text {th }}$. Heading date and final height were assessed in all plants and the other traits in three plants per plot.

Analyses of variance were performed on a plot mean basis with SAS software (SAS Institute 1994). Progeny means were compared by the Scott-Knot test, with Genes software (Cruz 2001). Comparisons with the check variety were made by the $t$ test. Variance components were estimated by the analysis of variance method using the software SAS (SAS Institute 1994). Additive genetic variances were estimated as indicated for half-sib progenies (Hallauer and Miranda Filho 1988):

$$
\sigma_{A}^{2}=4 \sigma_{h s p}^{2}
$$

where $\sigma_{h s p}^{2}$ is the variance component associated to the effects of half-sib progeny.

Narrow-sense heritabilities were estimated by the expression:

$$
h^{2}=\frac{\sigma_{h s p}^{2}}{\sigma_{h s p}^{2}+\frac{\sigma^{2}}{r}}
$$

where $\sigma^{2}$ is the variance component associated to the error and $r$ is the number of replications.

The selection gain was estimated for a scheme involving the selection among progenies and recombination through remnant seeds and is shown in absolute and percentual values.

Simple phenotypic correlations were estimated among all traits.

\section{RESULTS AND DISCUSSION}

Significant differences among treatments occurred for all traits (Table 1). With regard to $\mathrm{NH}$, the means of the progenies varied between 8.00 and $17.22 \mathrm{~cm}$, and the 
Table 1. Analysis of variance for natural height $(\mathrm{cm})$, plant diameter $(\mathrm{cm})$, heading date (days), final height $(\mathrm{cm})$ and tiller number in halfsib progenies of velvet grass

\begin{tabular}{|c|c|c|c|c|c|c|}
\hline S.V. & df & Natural height & Plant diameter & Heading date & Final height & Tiller number \\
\hline Blocks & 2 & 3.50 & 193.82 & 9.03 & 12.10 & 86.81 \\
\hline Progenies & 59 & $7.82 *$ & $40.09 *$ & 87.11* & $22.59 *$ & $150.89^{*}$ \\
\hline Error & 113 & 4.86 & 27.25 & 7.12 & 9.75 & 54.08 \\
\hline C.V. & & 16.76 & 20.31 & 1.62 & 7.03 & 27.93 \\
\hline $\mathrm{R}^{2}$ & & 0.46 & 0.46 & 0.86 & 0.55 & 0.60 \\
\hline
\end{tabular}

population mean was $13.14 \mathrm{~cm}$ (Table 2). Progenies were separated in two groups according to the Scott and Knott test. Plant diameter varied between 14.17 and $33.78 \mathrm{~cm}$, and two groups were formed (Table 2). These traits may be selected as estimates of early production. In a Brazilian population of Italian ryegrass, correlations with early dry matter production were 0.50 for natural height and 0.54 for diameter (Mittelmann et al. 2006). Castro et al. (2003) found an even higher value for the diameter $\mathrm{x}$ dry matter yield correlation (0.68).

Table 2. Means of 60 half-sib progenies of velvet grass for natural height $(\mathrm{cm})$ and plant diameter $(\mathrm{cm})$

\begin{tabular}{|c|c|c|c|c|c|c|c|}
\hline \multirow[b]{2}{*}{ Progeny } & \multicolumn{3}{|c|}{ Natural Height } & \multicolumn{4}{|c|}{ Plant diameter } \\
\hline & Mean & Progeny & Mean & Progeny & Mean & Progeny & Mean \\
\hline 25 & $17.22 \mathrm{a}^{*}$ & 225 & $12.67 \mathrm{~b}$ & 195 & $33.78 \mathrm{a}^{*}$ & 145 & $25.39 \mathrm{~b}$ \\
\hline 105 & $17.00 \mathrm{a}^{*}$ & 185 & $12.56 \mathrm{~b}$ & 95 & $31.17 \mathrm{a}$ & 220 & $25.33 b$ \\
\hline 45 & $16.78 \mathrm{a}^{*}$ & 270 & $12.56 \mathrm{~b}$ & 185 & $30.50 \mathrm{a}$ & 270 & $25.22 \mathrm{~b}$ \\
\hline 125 & $16.67 a^{*}$ & 80 & $12.44 \mathrm{~b}$ & 35 & $30.22 \mathrm{a}$ & 65 & $24.83 b$ \\
\hline 160 & $15.89 \mathrm{a}^{*}$ & 286 & $12.44 \mathrm{~b}$ & 210 & $30.06 \mathrm{a}$ & 90 & $24.78 b$ \\
\hline 95 & $15.44 \mathrm{a}$ & 110 & $12.22 \mathrm{~b}$ & 155 & $29.89 \mathrm{a}$ & 280 & $24.72 b$ \\
\hline 140 & $15.44 \mathrm{a}$ & 20 & $12.11 \mathrm{~b}$ & 15 & $29.78 \mathrm{a}$ & 245 & $24.61 \mathrm{~b}$ \\
\hline 90 & $15.00 \mathrm{a}$ & 180 & $12.11 \mathrm{~b}$ & 201 & $29.67 \mathrm{a}$ & 256 & $24.22 b$ \\
\hline 75 & $14.89 \mathrm{a}$ & 280 & $12.11 \mathrm{~b}$ & 105 & $29.61 \mathrm{a}$ & 20 & $24.22 b$ \\
\hline 145 & $14.56 \mathrm{a}$ & 30 & $12.00 \mathrm{~b}$ & 150 & $29.56 \mathrm{a}$ & 305 & $24.06 \mathrm{~b}$ \\
\hline 56 & $14.44 \mathrm{a}$ & 40 & $12.00 \mathrm{~b}$ & 215 & $29.39 \mathrm{a}$ & 253 & $23.44 \mathrm{~b}$ \\
\hline 65 & $14.44 \mathrm{a}$ & 50 & $12.00 \mathrm{~b}$ & 160 & $28.83 \mathrm{a}$ & 50 & $23.33 b$ \\
\hline 201 & $14.33 \mathrm{a}$ & 135 & $12.00 \mathrm{~b}$ & 165 & $28.78 \mathrm{a}$ & 25 & $23.06 \mathrm{~b}$ \\
\hline 130 & $14.22 \mathrm{a}$ & 150 & $11.89 \mathrm{~b}$ & 286 & $28.61 \mathrm{a}$ & 75 & $23.06 \mathrm{~b}$ \\
\hline 190 & $14.11 \mathrm{a}$ & 170 & $11.78 \mathrm{~b}$ & 170 & $28.61 \mathrm{a}$ & 267 & $23.00 \mathrm{~b}$ \\
\hline 35 & $14.00 \mathrm{~b}$ & 175 & $11.78 \mathrm{~b}$ & 175 & $28.61 \mathrm{a}$ & 225 & $22.94 \mathrm{~b}$ \\
\hline 215 & $14.00 \mathrm{~b}$ & 240 & $11.78 \mathrm{~b}$ & 40 & $28.50 \mathrm{a}$ & 80 & $22.89 b$ \\
\hline 70 & $13.83 \mathrm{~b}$ & 300 & $11.78 \mathrm{~b}$ & 290 & $28.39 \mathrm{a}$ & 6 & $22.72 b$ \\
\hline 290 & $13.67 \mathrm{~b}$ & 305 & $11.78 \mathrm{~b}$ & 140 & $28.33 \mathrm{a}$ & 238 & $22.39 \mathrm{~b}$ \\
\hline 15 & $13.56 \mathrm{~b}$ & 206 & $11.67 \mathrm{~b}$ & 45 & $28.28 \mathrm{a}$ & 110 & $21.78 \mathrm{~b}$ \\
\hline 210 & $13.44 \mathrm{~b}$ & 238 & $11.67 \mathrm{~b}$ & 240 & $28.28 \mathrm{a}$ & 70 & $21.75 b$ \\
\hline 245 & $13.44 \mathrm{~b}$ & 115 & $11.56 \mathrm{~b}$ & 100 & $27.89 \mathrm{a}$ & 30 & $21.17 \mathrm{~b}$ \\
\hline 155 & $13.33 b$ & 220 & $11.56 \mathrm{~b}$ & 190 & $27.61 \mathrm{a}$ & 295 & $20.89 b$ \\
\hline 6 & $13.22 \mathrm{~b}$ & 295 & $11.56 \mathrm{~b}$ & 180 & $27.22 \mathrm{a}$ & 206 & $20.33 b$ \\
\hline 120 & $13.22 \mathrm{~b}$ & 267 & $11.17 \mathrm{~b}$ & 10 & $26.78 \mathrm{a}$ & 115 & $19.56 b$ \\
\hline 165 & $13.22 \mathrm{~b}$ & 261 & $11.11 \mathrm{~b}$ & 56 & $26.06 \mathrm{a}$ & 230 & $18.94 b$ \\
\hline 86 & $13.11 \mathrm{~b}$ & 253 & $11.00 \mathrm{~b}$ & 261 & $25.94 \mathrm{a}$ & 135 & $18.61 \mathrm{~b}$ \\
\hline 100 & $13.11 \mathrm{~b}$ & 230 & $10.56 \mathrm{~b}$ & 125 & $25.61 \mathrm{~b}$ & 130 & $17.39 \mathrm{~b}$ \\
\hline 256 & $13.11 \mathrm{~b}$ & 310 & $8.00 \mathrm{~b}$ & 86 & $25.61 \mathrm{~b}$ & 310 & $14.17 \mathrm{~b}$ \\
\hline 10 & $13.00 \mathrm{~b}$ & Mean & 13.14 & 300 & $25.56 \mathrm{~b}$ & Mean & 25.70 \\
\hline 95 & $12.78 \mathrm{~b}$ & ontrol & 12.11 & 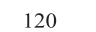 & $25.44 \mathrm{~b}$ & Control & 22.82 \\
\hline
\end{tabular}

Means followed by the same letter do not differ significantly through Scott \& Knott test with 5\% of significance.

* Differs significantly from the check through the t test with $5 \%$ of significance.
Heading date varied between 155.6 and 177.7 days and the population mean was 164.1 days (Table 4). For this trait, five groups of progenies were formed. Late flowering is usually desirable, extending the period of utilisation of the pasture. Final height varied among 38.03 and $50.13 \mathrm{~cm}$, with a mean of $44.44 \mathrm{~cm}$, and two groups of progenies were formed (Table 3). Concerning the number of tillers, the Scott and Knot test has pointed to only one group, despite the variation of the means, which ranged from 12.89 to 52.89 tillers per plant, and the significance through the F test (Table 3).

The check variety was the Uruguayan cultivar La Magnolia. For all traits, the population mean was superior to the check, indicating a potential for the selection of more adapted and productive cultivars. Regarding the cycle, there is a huge possibility of selection for late genotypes as well as for early genotypes, because there were also progenies with significantly lower means than the check.

Estimates of variance components associated to progeny effect and error are shown on Table 4 . The estimates of additive variance, were 4.06; 17.62; 109.76; 17.61 and 132.84 for $\mathrm{NH}(\mathrm{cm})$, diameter $(\mathrm{cm})$, heading date (days), final height $(\mathrm{cm}$ ) and tiller number, respectively.

Among the studied traits, heading date has shown the highest heritability, of 92\% (Table 4). This value indicates a low effect of the environment and that this trait is easy to select. It is possible that this population is segregating for a gene of large effect on the heading date. Final height and tiller number showed heritabilities that might be considered as intermediary values, while $\mathrm{NH}$ and diameter have low values (Table 4). It is important to consider that these heritability estimations are in a narrow sense, once the variance among half-sib progenies involves basically additive effects. In maize, the model plant to the study of allogamous species, average estimates of heritability of $56.9 \%$ for plant height, $57.9 \%$ for heading date and $71.9 \%$ for number of tillers were found (Hallauer and Miranda 1988). In meadow bromegrass (Bromus riparius Rehm.), Araújo and Coulman (2004) have found broad-sense heritabilities of $90 \%$ for height and $58 \%$ for diameter.

Estimated selection gains for one cycle of selection and $10 \%$ intensity indicated extremely favourable results, especially for tiller number, with a gain of $30.77 \%$ over the original population mean. The expected gains were of $8.28 \%$ for $\mathrm{NH} ; 8.11 \%$ for diameter; $5.37 \%$ for heading date and $6.25 \%$ for final height (Table 4). Natural populations, which were not submitted to selection, usually show large 
Half-sib progenies evaluation in velvet grass

Table 3. Means of 60 progenies of half-sibs for heading date (days), final height $(\mathrm{cm})$ and tiller number

\begin{tabular}{|c|c|c|c|c|c|c|c|c|c|c|c|}
\hline \multicolumn{4}{|c|}{ Heading date } & \multicolumn{4}{|c|}{ Final height } & \multicolumn{4}{|c|}{ Tiller number } \\
\hline Progeny & Mean & Progeny & Mean & Progeny & Mean & Progeny & Mean & Progeny & Mean & Progeny & Mean \\
\hline 310 & $177.70 \mathrm{a}^{*}$ & 100 & $161.98 \mathrm{~d}$ & 286 & $50.13 a^{*}$ & 40 & $43.93 b$ & 240 & $52.89 a^{*}$ & 270 & $26.00 \mathrm{a}$ \\
\hline 267 & $174.81 \mathrm{a}^{*}$ & 135 & $161.83 \mathrm{~d}$ & 225 & $49.90 a^{*}$ & 245 & $43.92 b$ & 280 & $51.44 a^{*}$ & 70 & $25.67 \mathrm{a}$ \\
\hline 201 & $174.02 \mathrm{a}^{*}$ & 56 & $161.80 \mathrm{~d}$ & 170 & $49.60 a^{*}$ & 56 & $43.80 \mathrm{~b}$ & 10 & $36.33 \mathrm{a}^{*}$ & 86 & $25.56 \mathrm{a}$ \\
\hline 165 & $173.11 \mathrm{a}^{*}$ & 215 & $161.71 \mathrm{~d}$ & 100 & $48.63 \mathrm{a}$ & 190 & $43.78 b$ & 165 & $35.33 \mathrm{a}^{*}$ & 190 & $25.11 \mathrm{a}$ \\
\hline 280 & $173.03 \mathrm{a}^{*}$ & 95 & $161.36 \mathrm{~d}$ & 201 & $48.62 \mathrm{a}$ & 130 & $43.64 b$ & 95 & $34.44 a^{*}$ & 110 & $24.78 \mathrm{a}$ \\
\hline 270 & $172.94 a^{*}$ & 180 & $161.28 \mathrm{~d}$ & 86 & $48.57 \mathrm{a}$ & 30 & $43.58 b$ & 215 & $33.11 \mathrm{a}^{*}$ & 290 & $24.78 \mathrm{a}$ \\
\hline 261 & $172.73 a^{*}$ & 30 & $161.20 \mathrm{~d}$ & 105 & $47.56 \mathrm{a}$ & 215 & $43.43 b$ & 267 & $32.83 a$ & 80 & $24.56 \mathrm{a}$ \\
\hline 225 & $172.17 a^{*}$ & 65 & $161.08 \mathrm{~d}$ & 15 & $47.51 \mathrm{a}$ & 185 & $43.42 b$ & 225 & $32.56 \mathrm{a}^{*}$ & 125 & $24.44 \mathrm{a}$ \\
\hline 238 & $171.50 a^{*}$ & 86 & $161.04 d$ & 195 & $47.10 \mathrm{a}$ & 253 & $43.34 b$ & 210 & $31.44 \mathrm{a}$ & 261 & $24.11 \mathrm{a}$ \\
\hline 206 & $171.45 \mathrm{a}^{*}$ & 245 & $160.99 \mathrm{~d}$ & 210 & $47.05 \mathrm{a}$ & 125 & $43.33 b$ & 195 & $31.22 \mathrm{a}$ & 20 & $23.89 \mathrm{a}$ \\
\hline 170 & $171.43 a^{*}$ & 35 & $160.94 d$ & 155 & $47.04 \mathrm{a}$ & 50 & $42.98 b$ & 40 & $30.67 \mathrm{a}$ & 253 & $23.67 \mathrm{a}$ \\
\hline 230 & $171.38 \mathrm{a}^{*}$ & 25 & $160.93 d$ & 165 & $46.82 \mathrm{a}$ & 230 & $42.73 b$ & 45 & $29.89 \mathrm{a}$ & 230 & $23.61 \mathrm{a}$ \\
\hline 256 & $171.03 \mathrm{a}^{*}$ & 6 & $160.59 \mathrm{~d}$ & 270 & $46.78 \mathrm{a}$ & 267 & $42.71 b$ & 286 & $29.44 a$ & 56 & $22.56 \mathrm{a}$ \\
\hline 295 & $169.75 b^{*}$ & 130 & $160.50 \mathrm{~d}$ & 261 & $46.72 \mathrm{a}$ & 305 & $42.37 b$ & 105 & $29.44 \mathrm{a}$ & 90 & $22.11 \mathrm{a}$ \\
\hline 253 & $169.09 \mathrm{~b}$ & 75 & $160.22 \mathrm{e}^{*}$ & 280 & $46.72 \mathrm{a}$ & 35 & $42.21 \mathrm{~b}$ & 145 & $29.44 \mathrm{a}$ & 65 & $21.11 \mathrm{a}$ \\
\hline 300 & $168.57 b$ & 305 & $159.96 \mathrm{e}^{*}$ & 75 & $46.70 \mathrm{a}$ & 310 & $42.20 \mathrm{~b}$ & 185 & $29.11 \mathrm{a}$ & 160 & $21.11 \mathrm{a}$ \\
\hline 210 & $168.32 b$ & 105 & $159.28 \mathrm{e}^{*}$ & 256 & $46.51 \mathrm{a}$ & 150 & $42.12 b$ & 15 & $28.89 a$ & 75 & $20.44 a$ \\
\hline 195 & $167.79 b$ & 40 & $159.17 \mathrm{e}^{*}$ & 135 & $46.47 \mathrm{a}$ & 90 & $41.94 b$ & 206 & $28.67 \mathrm{a}$ & 220 & $20.44 a$ \\
\hline 190 & $166.33 b$ & 160 & $159.04 \mathrm{e}^{*}$ & 70 & $46.36 \mathrm{a}$ & 240 & $41.87 \mathrm{~b}$ & 155 & $28.33 \mathrm{a}$ & 238 & $20.44 a$ \\
\hline 290 & $165.94 \mathrm{c}$ & 120 & $158.93 \mathrm{e}^{*}$ & 206 & $46.23 \mathrm{a}$ & 10 & $41.50 \mathrm{~b}$ & 175 & $28.33 \mathrm{a}$ & 295 & $19.33 \mathrm{a}$ \\
\hline 286 & $165.68 \mathrm{c}$ & 145 & $158.54 \mathrm{e}^{*}$ & 120 & $45.79 a$ & 20 & $41.29 b$ & 170 & $27.89 \mathrm{a}$ & 310 & $19.33 \mathrm{a}$ \\
\hline 70 & $165.60 \mathrm{c}$ & 15 & $157.72 \mathrm{e}^{*}$ & 115 & $45.35 \mathrm{a}$ & 180 & $41.16 b$ & 256 & $27.56 \mathrm{a}$ & 245 & $19.11 \mathrm{a}$ \\
\hline 175 & $165.60 \mathrm{c}$ & 110 & $157.59 \mathrm{e}^{*}$ & 300 & $45.05 \mathrm{a}$ & 6 & $40.70 \mathrm{~b}$ & 100 & $27.44 \mathrm{a}$ & 6 & $18.89 \mathrm{a}$ \\
\hline 115 & $165.50 \mathrm{c}$ & 90 & $157.55 \mathrm{e}^{*}$ & 140 & $44.89 \mathrm{a}$ & 175 & $40.49 b$ & 120 & $27.44 a$ & 30 & $17.00 \mathrm{a}$ \\
\hline 220 & $165.38 \mathrm{c}$ & 125 & $157.17 \mathrm{e}^{*}$ & 65 & $44.85 \mathrm{a}$ & 110 & $40.20 \mathrm{~b}$ & 150 & $27.22 \mathrm{a}$ & 180 & $16.78 \mathrm{a}$ \\
\hline 10 & $163.61 \mathrm{c}$ & 20 & $157.04 \mathrm{e}^{*}$ & 45 & $44.65 b$ & 220 & $40.11 b$ & 140 & $27.11 \mathrm{a}$ & 135 & $15.22 \mathrm{a}$ \\
\hline 155 & $163.51 \mathrm{c}$ & 45 & $156.40 \mathrm{e}^{*}$ & 25 & $44.58 b$ & 80 & $40.01 b$ & 300 & $27.00 \mathrm{a}$ & 50 & $14.67 \mathrm{a}$ \\
\hline 185 & $163.47 \mathrm{c}$ & 80 & $156.22 \mathrm{e}^{*}$ & 95 & $44.51 \mathrm{~b}$ & 290 & $40.01 \mathrm{~b}$ & 201 & $26.56 a$ & 130 & $13.89 \mathrm{a}$ \\
\hline 50 & $163.30 \mathrm{c}$ & 140 & $155.60 \mathrm{e}^{*}$ & 295 & $44.49 b$ & 238 & $38.03 \mathrm{~b} *$ & 115 & $26.56 \mathrm{a}$ & 25 & $12.89 \mathrm{a}$ \\
\hline 240 & $162.57 \mathrm{~d}$ & Mean & 164.08 & 160 & $44.39 \mathrm{~b}$ & Mean & 44.44 & 305 & $26.44 a$ & Mean & 26.33 \\
\hline 150 & $162.56 \mathrm{~d}$ & Control & 164.84 & 145 & $44.00 \mathrm{~b}$ & Control & 43.73 & 35 & $26.44 \mathrm{a}$ & Control & 20.53 \\
\hline
\end{tabular}

Means followed by the same letter do not differ significantly through Scott \& Knott test with $5 \%$ of significance.

* Differs significantly from the control through the t test with $5 \%$ of significance.

genetic variability, allowing high gains in the first cycles of selection. Due to the high heritability, an extremely high genetic gain, of 8.81 days, is expected for heading date.

There were associations among traits, except for $\mathrm{NH}$ and tiller number, and heading date and tiller number. In general, the correlation values were low (Table 5). The highest value found was among the plant diameter and tiller number $(\mathrm{r}=0.43)$. The $\mathrm{NH}$ and diameter traits measured in the initial stage of the plant development with the objective of selecting for early dry matter production has shown a certain degree of association ( $r=0.35$ ), besides having a negative correlation with heading date, which might point to a tendency of delayed flowering progenies for having a slower initial development. Mittelmann et al. (2004) have found similar correlations, and considered that they are of low value and do not hind the selection for an extended cycle of utilization of the pasture.

Data discussed here leads us to the conclusions that there is intrapopulation genetic variability for all the studied traits and gains after selection among half-sib progenies can be expected, and that a small number of genes control heading date variability in this population. 
A Mittelmann and ED Buchweitz

Table 4. Estimations of the variance components of progenies $\left(\sigma_{\text {hsp }}^{2}\right)$ and error $\left(\sigma^{2}\right)$, additive variance $\left(\sigma_{A}^{2}\right)$, heritability and selection gain in absolute (Gs) and percentual (Gs\%) value for natural height $(\mathrm{NH}, \mathrm{cm})$, plant diameter $(\mathrm{cm})$, heading date (days), final height $(\mathrm{cm})$ and tiller number

\begin{tabular}{cccccc}
\hline & Natural height & Plant diameter & Heading date & Final height & Tiller number \\
\hline$\sigma_{h s p}^{2}$ & $1.01 \pm 0.53$ & $4.40 \pm 2.77$ & $27.44 \pm 5.44$ & $4.40 \pm 1.47$ & $33.21 \pm 9.68$ \\
$\sigma^{2}$ & $4.86 \pm 0.64$ & $27.25 \pm 3.59$ & $7.12 \pm 0.94$ & $9.75 \pm 1.29$ & $54.08 \pm 7.13$ \\
$\sigma_{A}^{2}$ & 4.06 & 17.62 & 109.76 & 17.61 & 132.84 \\
$h^{2}$ & 0.38 & 0.32 & 0.92 & 0.57 & 0.64 \\
$\mathrm{Gs}$ & 1.09 & 2.08 & 8.81 & 2.78 & 8.10 \\
$\mathrm{Gs} \%$ & 8.28 & 8.11 & 5.37 & 6.25 & 30.77 \\
\hline
\end{tabular}

Table 5. Simple phenotypic correlations between traits in a velvet grass population

\begin{tabular}{lcccc}
\hline & Diameter & Heading date & Final height & Tiller number \\
\hline Natural height & $0.35^{* *}$ & $-0.38^{* *}$ & $0.23^{* *}$ & 0.08 \\
Diameter & & $-0.18^{*}$ & $0.26^{* *}$ & $0.43^{* *}$ \\
Heading date & & & $0.15^{*}$ & 0.10 \\
Final height & & & & $0.28^{* *}$ \\
\hline$* * *$ Significant at $1 \%$ and $5 \%$ probability, respectively.
\end{tabular}

\section{ACKNOWLEDGEMENTS}

We thank Dr. José Carlos Leite Reis, from Embrapa Agricultura Temperada, for offering us the knowledge and bibliography gathered during years of research regarding the present species.

\section{Avaliação de progênies de meios-irmãos de capim- lanudo}

RESUMO - O capim-lanudo (Holcus lanatus L.) possui grande potencial de utilização como pastagem de inverno nas regiões subtropicais, devido a seu bom estabelecimento, persistência, produção, resistência ao frio, palatabilidade e capacidade de afilhamento. O objetivo deste trabalho foi estimar a variabilidade genética e a herdabilidade de caracteres agronômicos e identificar progênies superiores. Foram avaliadas 60 progênies de meios-irmãos, para altura (NH) e diâmetro da planta na fase vegetativa, duração do ciclo vegetativo (ciclo), altura final (FH) e número de afilhos. Houve diferença entre progênies para todos os caracteres. As estimativas de herdabilidade foram de 38\%, 32\%, 92\%, 57\% e 64\% para NH, diâmetro, ciclo, FH e afilhos, respectivamente. O maior ganho genético estimado foi de 30,77 \% para o número de afilhos. Existe variabilidade para todos os caracteres e são esperados ganhos na seleção entre progênies.

Palavras-chave: Pastagem, Holcus lanatus, variância aditiva, herdabilidade, ganho de seleção.

\section{REFERENCES}

Araújo AA (1956) Pastagens artificiais. Criação e Lavoura 21 123-125

Araújo MRA and Coulman B (2004) Genetic variation and correlation of agronomic traits in meadow bromegrass (Bromus riparius Rehm) clones. Ciência Rural 34: 505-510.

Bemhaja M (1993) Holcus lanatus L. “La Magnólia”. INIA, Tacuarembó, 15p. (Serie Técnica, 32).

Castro CM, Oliveira AC, Carvalho FIF, Maia MS, Mattos LA and Freitas F (2003) Morphological and molecular characterization of Italian ryegrass populations. Crop Breeding and Applied Biotechnology 3: 245-254.
Cruz CD (2001) Programa Genes versão Windows: aplicativo computacional em genética e estatística. Editora UFV, Viçosa, 642p.

Gomes JF and Reis JCL (2000) Produção de espécies forrageiras perenes de estação fria no litoral sul do Estado do Rio Grande do Sul. Agropecuária Clima Temperado 3: 131-138.

Hallauer AR and Miranda JB (1988) Quantitative genetics in maize breeding. 2.ed. Iowa State University Press, Iowa, 468p.

Klitsch C (1965) Produccion de forrajes. Acribia, Zaragoza, 335p.

Crop Breeding and Applied Biotechnology 10: 254-259, 2010 
Mittelmann A, Moraes COC, Poli CHEC, Neske MZ, Brandolt TL, Anillo LC (2004) Variabilidade entre plantas de azevém para caracteres relacionados à precocidade. Ciência Rural 34: 1249-1250.

Mittelmann A, Buchweitz ED and Goulart ES (2006) Indirect selection of forage yield in Italian ryegrass. Crop Breeding and Applied Biotechnology 6: 104-106.

Moraes COC (2000) Comparação de Bromus auleticus Trinius com outras gramíneas perenes de inverno. Embrapa Pecuária Sul, Bagé, 15p. (Boletim de Pesquisa, 19)

Oliveira JCP, Dutra GM and Moraes COC (2001) Alternativas forrageiras para sistemas de produção pecuária. Embrapa Pecuária Sul, Bagé, 14p. (Documentos, 29)
Pitcher D and Russo MJ (2003) Element stewardship abstract for Holcus lanatus. The Nature Conservancy, Arlington. Available at http://www.tncweeds.ucdavis.edu/esadocs/documnts/ holclan.pdf. Accessed on 08 July, 2003.

Rumball W (1980) Other grasses. In Wratt GS and Smith HC (Ed.) Plant breeding in New Zealand. D.S.I.R., Butterworths, p. 263-270.

SAS Institute (1994) SAS/STAT procedure guide for personal computers. Version 5. SAS Institute, Cary.

Watt TA (1978) The biology of Holcus lanatus L. (Yorkshire fog) and its significance in grassland. Herbage Abstracts 48: 195204. 